\title{
Effects of angiotensin II on the acrosome reaction in equine spermatozoa
}

\author{
K. Sabeur, A. T. Vo and B. A. Ball* \\ Department of Population Health and Reproduction, Room 1114 Tupper Hall, University of California, Davis, CA 95616, USA
}

\begin{abstract}
Angiotensin II is a hormone with a wide array of physiological effects that exerts its effect via interaction with two major subtypes of receptor. The results of this study show that angiotensin II (from 1 to $100 \mathrm{nmol} \mathrm{l}^{-1}$ ) initiates acrosomal exocytosis in equine spermatozoa that have undergone capacitation in vitro in a TALP-TEST (Tyrode's albumin lactate pyruvate; $188.7 \mathrm{mmol}$ TES $\mathrm{l}^{-1}, 84.8 \mathrm{mmol}^{\text {Tris }} \mathrm{l}^{-1}$ ) buffer with cAMP. The acrosome reaction and sperm viability were assessed with fluorescein isothiocyanatePisum sativum agglutinin (FITC-PSA) and Hoechst 33258, respectively. The initiation of the acrosome reaction by angiotensin II was strongly inhibited by losartan, a specific angiotensin II type 1 receptor antagonist. Although angiotensin II as well as progesterone both initiated the acrosome reaction in equine spermatozoa, there was no synergistic effect when both agonists were added simultaneously. Initiation of acrosomal exocytosis by angiotensin II was accompanied by a rapid and transient calcium influx that was assessed in capacitated spermatozoa loaded with Fura-2AM. In addition, the angiotensin II-mediated calcium influx was inhibited when spermatozoa were preincubated with losartan. Western blotting with an antibody against angiotensin II type 1 receptor detected a major sperm protein of $60 \mathrm{kDa}$. Indirect immunofluorescence of non-capacitated spermatozoa with the angiotensin II type 1 receptor antibody revealed labelling in the midpiece and tail. In capacitated spermatozoa, the angiotensin II type 1 receptor was localized mainly over the anterior region of the sperm head, the equatorial segment and occasionally on the postacrosomal region in addition to the sperm tail. In conclusion, this study demonstrated the ability of angiotensin II to stimulate the acrosome reaction in capacitated equine spermatozoa. This effect is mediated via the angiotensin II type 1 receptor and is accompanied by an increase in intracellular calcium.
\end{abstract}

\section{Introduction}

The mammalian acrosome reaction, an exocytotic event in spermatozoa, is a prerequisite for fertilization. Acrosomal exocytosis involves the fusion of the outer acrosomal membrane with the overlying sperm plasma membrane, resulting in the release of acrosomal contents. In vivo, the acrosome reaction is triggered by contact with the zona pellucida, an acellular glycoprotein surrounding the egg. The acrosome reaction can also be initiated in vitro by other agonists including progesterone, a steroid secreted by the cumulus oophorus (Tesarik, 1985; Osman et al., 1989; Meizel and Turner, 1991), atrial natriuretic peptides (Zamir et al., 1993), prostaglandins (Joyce et al., 1987; Lax et al., 1994; Schaefer, 1998), and epidermal growth factors (Furuya et al., 1993; Naz and Kaplan, 1993). More recently, angiotensin II has been shown to induce the acrosome reaction in bovine and human spermatozoa (Gur et al., 1998; Kohn et al., 1998).

${ }^{*}$ Correspondence.

Received 25 January 2000.
Angiotensin II is one of the main components of the renin-angiotensin system (RAS), which is classically considered as a systemic enzyme cascade that is important in blood pressure and electrolyte homeostasis. The first ten amino acids of a precursor protein, angiotensinogen represent angiotensin I, which is released under the action of renin. The decapeptide angiotensin I is rapidly converted to the active octapeptide, angiotensin II, by angiotensin converting enzyme (ACE). Angiotensin II induces a remarkable variety of physiological responses in different types of cell.

Although the impact of RAS on reproduction is not yet completely understood, there is increasing evidence that RAS can modulate reproductive function. The presence of components of RAS and specific receptors for angiotensin II in the female and male reproductive tracts supports the hypothesis that aspects of reproductive function may be regulated by RAS. The ovary appears to have a local RAS. Angiotensin II is present in the ovary and is abundant in human follicular fluid. In addition to its autocrine and paracrine effect, angiotensin II produced locally in the female tract may affect sperm function directly. 
Angiotensin II exerts its effects on various tissues by interacting with two types of cell surface receptors classified as type 1 (AT1) and type 2 (AT2) receptors. The AT1 receptor is characterized as a high-affinity, thiol sensitive receptor, and the AT2 receptor is a low-affinity, thiol insensitive receptor. Almost all of the known biological actions of AII are believed to be mediated by the AT1 receptor (Vinson et al., 1995).

This laboratory has previously isolated and characterized a protein with homology to ACE from the periacrosomal membrane of equine spermatozoa (Dobrinski et al., 1997) and is interested in investigating the potential roles of some of the RAS components in equine sperm function. The aim of the present study was to investigate the effect of angiotensin II on the acrosome reaction and calcium release in equine spermatozoa as well as the presence of angiotensin II type 1 receptors on equine spermatozoa.

\section{Materials and Methods}

Semen was collected by artificial vagina from stallions that were housed individually at the Department of Animal Science or Veterinary Medical Teaching Hospital, University of California, Davis.

Human angiotensin II was purchased from Bachem (Torrance, CA). The angiotensin II type 1 receptor antagonist losartan was obtained from Merck (WestPoint, PA). Fura2AM and Hoechst 33258 were purchased from Molecular Probes (Eugene, OR). BSA (fraction V) was obtained from Calbiochem (La Jolla, CA), and fluorescein isothiocyanate (FITC)-PSA was obtained from Vector Laboratories (Burlingame, CA). The electrophoresis reagents were obtained from Biorad (Hercules, CA), and all other reagents were obtained from Sigma Chemical Co. (St Louis, MO).

\section{Sperm capacitation}

Equine spermatozoa were washed on a two-step Percoll gradient $(80: 40 \%)$ and were centrifuged twice at $300 \mathrm{~g}$ for $20 \mathrm{~min}$ and $10 \mathrm{~min}$ (Meyers et al., 1995). After the last wash, spermatozoa were diluted to $12 \times 10^{6} \mathrm{ml}^{-1}$ in Tyrode's albumin lactate pyruvate (TALP) capacitation buffer, $\mathrm{pH} 7.4$, as described by Meyers et al. (1995). Metabolites containing sodium lactate, sodium pyruvate but no glucose were added with penicillin $\mathrm{G}$ (50 iu ml-1 final concentration), streptomycin (5 $\mathrm{g} \mathrm{m} \mathrm{ml}^{-1}$ final concentration), $20 \mathrm{mg} \mathrm{BSA} \mathrm{ml}^{-1}$ (fraction V) and $0.1 \%$ polyvinyl alcohol (PVA). The TALP medium was mixed (50:50, v/v) with a complete TEST (188.7 TES mmol ${ }^{-1}$, $84.8 \mathrm{mmol}$ Tris $\mathrm{l}^{-1}$ )-egg yolk buffer as described by Meyers et al. (1995). Spermatozoa were capacitated in polypropylene tubes for $3.5 \mathrm{~h}$ at $39^{\circ} \mathrm{C}$ in the presence of $500 \mu \mathrm{mol} 8 \mathrm{Br}-\mathrm{cAMP}$ $1^{-1}$ (Parrish et al., 1998). A small aliquot (5 $\left.\mu \mathrm{l}\right)$ was used for determination of the percentage of motile spermatozoa and for subjective estimation of the quality of sperm motility (Thomas and Meizel, 1988).

\section{Induction of the acrosome reaction}

After capacitation, sperm motility was assessed and spermatozoa were treated with angiotensin II at concentrations varying from 1000 to $1 \mathrm{nmol} \mathrm{l}^{-1}$ (final concentrations) or progesterone $\left(3.18 \mu \mathrm{mol} \mathrm{^{-1 }}\right)$ for $20 \mathrm{~min}$ to induce acrosomal exocytosis (Expt 1). In Expt 2, spermatozoa were preincubated with the angiotensin II type 1 receptor antagonist losartan $\left(100 \mathrm{nmol} \mathrm{l}^{-1}\right)$ for $10 \mathrm{~min}$ before the addition of angiotensin II $\left(100 \mathrm{nmol} \mathrm{l}^{-1}\right)$ for another $20 \mathrm{~min}$. In Expt 3, capacitated spermatozoa were treated with progesterone or angiotensin II, alone or in combination, for $20 \mathrm{~min}$. These experiments were repeated in three or four different stallions; two ejaculates per stallion were used.

\section{Acrosomal and viability staining of equine spermatozoa}

After capacitation and the acrosome reaction, Hoechst 33258 was added to $200 \mu \mathrm{l}$ sperm suspension (final concentration $1 \mu \mathrm{g} \mathrm{ml}^{-1}$ ). Spermatozoa were incubated for $8 \mathrm{~min}$ at $39^{\circ} \mathrm{C}$ and fixed in $2 \%(\mathrm{v} / \mathrm{v})$ paraformaldehyde for an additional $10 \mathrm{~min}$ at $22^{\circ} \mathrm{C}$. Sperm suspensions $(20 \mu \mathrm{l})$ were applied to a filter, washed in Dulbecco's PBS (DPBS) and fixed in $100 \%$ cold ethanol for $10 \mathrm{~min}$. After washing with DPBS and blocking with BSA-DPBS, spermatozoa were stained with FITC-PSA for 10 min for acrosome evaluation. Spermatozoa were scored for viability and acrosomal status using epifluorescence microscopy. A total of 200 spermatozoa was assessed for each sample, and acrosomal status was scored without knowledge of treatment groups. Four categories of acrosomal labelling were scored according to the criteria of Cross et al. (1986): viable and acrosome intact; viable and acrosome reacted; dead and acrosome intact; dead and acrosome reacted.

\section{Calcium measurements}

Intracellular calcium was determined according to the procedures of Thomas and Meizel (1988). After Percoll centrifugation, spermatozoa were resuspended at $12 \times 10^{6} \mathrm{ml}^{-1}$ in $500 \mu \mathrm{l}$ aliquots in TALP (2\%) BSA (0.1\%) PVA medium and TEST-egg yolk buffer (50:50, v/v) (Meyers et al., 1995) in the presence of 8 br-cAMP. After $3.5 \mathrm{~h}$ capacitation at $39^{\circ} \mathrm{C}$, aliquots of spermatozoa were pooled ( $2 \mathrm{ml}$ per tube). Fura-2AM was added to the sperm suspensions at a concentration of $1 \mu \mathrm{mol}{ }^{-1}$ and the spermatozoa were incubated for an additional $30 \mathrm{~min}$ at $39^{\circ} \mathrm{C}$. Each $2 \mathrm{ml}$ sample was centrifuged through $40 \%(\mathrm{v} / \mathrm{v})$ Percoll (300 $\mathrm{g}$ for $15 \mathrm{~min}$ ), washed and resuspended in TALP medium, and equilibrated in a fluorometric cuvette. Fluorescence caused by the binding of calcium to Fura-2 was monitored with a Hitachi F-2000 spectrofluorometer with dual excitation wavelengths of 340 and $380 \mathrm{~nm}$ and an emission wavelength of $510 \mathrm{~nm}$. Intracellular calcium was computed using a $K_{\mathrm{d}}$ value of $285 \mathrm{nmol}^{-1}$ for Fura-2AM.

The same samples $(200 \mu \mathrm{l})$ used for the calcium studies but without Fura-2AM were aliquoted and used for acrosome reaction evaluation.

\section{Immunoblotting for detection of angiotensin II type 1 receptor}

Raw equine semen was centrifuged twice in TALP $(0.1 \%)$ PVA, pH 7.4 at $300 \mathrm{~g}$ for $10 \mathrm{~min}$. The sperm pellet was resuspended in TALP-PVA, and a small aliquot was used to 
assess motility and sperm concentration. Protease inhibitors were added from stock solutions at the following final concentrations: $100 \mu \mathrm{mol}$ phenylmethylsulfonyl fluoride (PMSF) $1^{-1}, 1 \mu \mathrm{mol}$ pepstatin $\mathrm{l}^{-1}, 5 \mu \mathrm{mol}$ leupeptin $\mathrm{l}^{-1}$, and $25 \mu \mathrm{mol}$ antipain $1^{-1}$. Spermatozoa were incubated with $1 \%$ $(\mathrm{v} / \mathrm{v})$ Triton-X100 and vortexed for $10 \mathrm{~min}$, and centrifuged at $10000 \mathrm{~g}$ for $15 \mathrm{~min}$. The supernatant was aliquoted and stored at $-20^{\circ} \mathrm{C}$ for use in SDS-PAGE. Proteins were separated on $12 \%$ SDS-PAGE and electrophoretically transferred to nitrocellulose membranes. The membranes were blocked with $5 \%(\mathrm{w} / \mathrm{v})$ milk TBS-T $\left(10 \mathrm{mmol}\right.$ Tris $\mathrm{l}^{-1}, 150 \mathrm{mmol} \mathrm{NaCl}$ $\mathrm{l}^{-1}, 0.1 \%(\mathrm{v} / \mathrm{v})$ Tween 20, pH 7.4) for $1 \mathrm{~h}$. Primary antibody incubation (angiotensin II type 1 receptor, N10, Santa Cruz Biotech, Santa Cruz, CA) was performed for $1 \mathrm{~h}$ at $25^{\circ} \mathrm{C}$ (1:2000). Membranes were washed four times in TBS-T for $10 \mathrm{~min}$ each and incubated with secondary antibody (horseradish peroxidase-conjugated goat anti-rabbit IgG in TBS-T, 1:5000) for $1 \mathrm{~h}$ at $25^{\circ} \mathrm{C}$. Membranes were washed four times for $10 \mathrm{~min}$ before detection of immunoreactive proteins by enhanced chemiluminescence (Amersham, Arlington Heights, IL). The specificity of the antibody was checked by the following control experiments: substitution of the primary antibody with buffer only, replacement of primary antibody with rabbit non-immune serum, preadsorption of the primary antibody with excess peptide antigen (SC-1173 P, Santa Cruz Biotech) using the manufacturer's protocol. A positive control (equine adrenal gland) was also used to confirm the presence of angiotensin II type 1 receptor (data not shown).

\section{Immunocytochemistry}

Capacitated or non-capacitated spermatozoa were diluted in TALP-1\% BSA, centrifuged twice at $300 \mathrm{~g}$ for $10 \mathrm{~min}$ and resuspended in DPBS at $50 \times 10^{6} \mathrm{ml}^{-1}$. Spermatozoa were permeabilized in $95 \%$ methanol for $5 \mathrm{~min}$, centrifuged at $300 \mathrm{~g}$ for $8 \mathrm{~min}$ and resuspended in DPBS before an additional centrifugation. The samples were incubated in blocking solution (DPBS-10\% goat serum) for $10 \mathrm{~min}$ followed by incubation in the primary angiotensin II type 1 receptor antibody (1:50) for $2 \mathrm{~h}$. Samples were washed in DPBS and resuspended in FITC-conjugated secondary antibody for $1 \mathrm{~h}$. Control experiments were run with secondary antibody only or replacement of primary antibody with rabbit non-immune serum.

\section{Statistical analysis}

Data were analysed by ANOVA (StatView, Cary, NC). Differences between treatments were assessed with Fisher's protected least significant difference test (StatView), and by regression analysis. Means were considered different at $P<0.05$. Results are expressed as mean $\pm \mathrm{SD}$.

\section{Results}

\section{Effect of angiotensin II on the acrosome reaction}

Viability and acrosomal integrity were expressed as the percentage of live acrosome-reacted spermatozoa over total

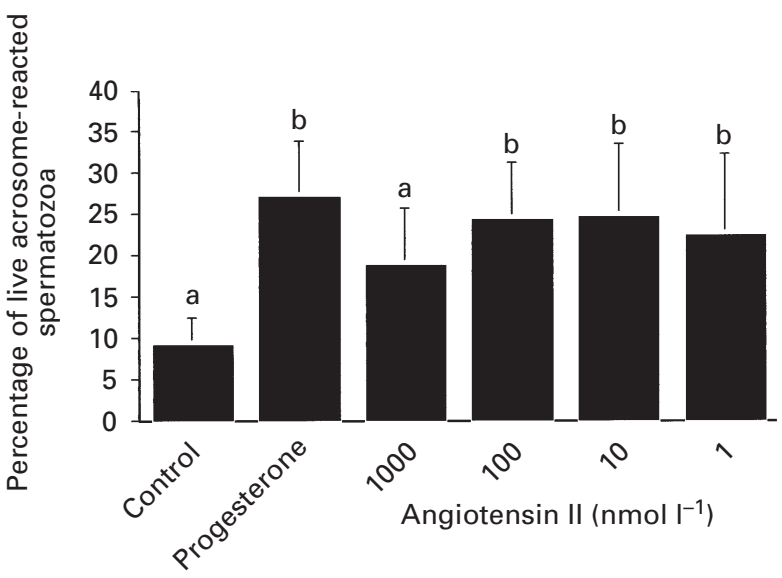

Fig. 1. The effect of angiotensin II $\left(0,1,10,100\right.$ or $\left.1000 \mathrm{nmol} \mathrm{l}^{-1}\right)$ or progesterone $\left(3.18 \mu \mathrm{mol} \mathrm{l}^{-1}\right)$ on acrosomal exocytosis in capacitated equine spermatozoa. Spermatozoa were capacitated for $3.5 \mathrm{~h}$ in the presence of $500 \mu \mathrm{mol}$ cAMP $1^{-1}$. The presence or absence of the acrosome was determined by staining with fluorescein isothiocyanate (FITC)-PSA and viability was determined by staining with Hoescht 33258. Data are presented as live acrosome-reacted spermatozoa as a percentage of total live spermatozoa. Values are means \pm SD of two ejaculates each from four individual stallions. Values with different letters are significantly different $(P<0.05)$.

live spermatozoa, because there were no significant differences between any of the treatments in the total number of live versus dead spermatozoa. The addition of angiotensin II in doses ranging from 1 to $100 \mathrm{nmol} \mathrm{l}^{-1}$ (Fig. 1) to capacitated cells for $20 \mathrm{~min}$ resulted in a significant increase $(P<0.05)$ in the percentage of live acrosome-reacted spermatozoa $(24.9-22.6 \%$ in treated spermatozoa versus $9.8 \%$ in controls). Maximum stimulation appeared to occur with 100 and $10 \mathrm{nmol}$ angiotensin II $\mathrm{l}^{-1}$. At higher concentrations $\left(1000 \mathrm{nmol} \mathrm{l}^{-1}\right)$, the stimulatory effect was not significant. In non-capacitated cells, there was no effect of angiotensin II on the percentage of live acrosome-reacted spermatozoa $(4.3 \pm 1.2$ to $8.5 \pm 1.0 \%)$ at all concentrations of angiotensin II, and this was not significantly different from the control value $(9.3 \pm 0.9 \%, n=3)$.

\section{Effect of losartan on the angiotensin-induced acrosome reaction}

Losartan (2 butyl-4 chloro-1[ $p$-o-1H-tetrazol-5-ylphenyl)benzyl]imidazole-5-methanol monopotassium salt) (100 nmol $\left.1^{-1}\right)$, a specific angiotensin II antagonist, significantly $(P<0.05)$ inhibited the angiotensin II-induced acrosome reaction (Fig. 2). However, losartan alone had no significant effect on the acrosome reaction.

\section{Effect of progesterone and angiotensin II on the acrosome reaction}

Progesterone $\left(3.18 \mu \mathrm{mol}^{-1}\right)$ alone resulted in an approximate threefold increase in the acrosome reaction in 


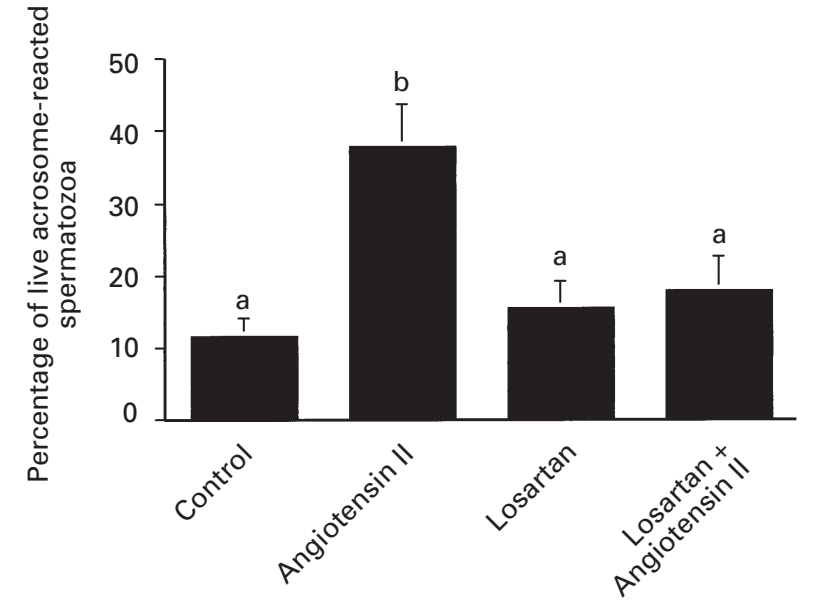

Fig. 2. Effect of the angiotensin II receptor inhibitor losartan $\left(100 \mathrm{nmol} \mathrm{l}^{-1}\right)$ on acrosomal exocytosis induced by angiotensin II in capacitated equine spermatozoa. Capacitated spermatozoa were preincubated with losartan for 10 min before the addition of angiotensin II $\left(100 \mathrm{nmol} \mathrm{l}^{-1}\right)$. Data are presented as live acrosomereacted spermatozoa as a percentage of total live spermatozoa. Values are means \pm SD from four individual stallions. Values with different letters are significantly different $(P<0.05)$.

capacitated equine spermatozoa. Capacitated spermatozoa were incubated with progesterone $\left(3.18 \mu \mathrm{mol} \mathrm{l}^{-1}\right)$ and angiotensin II $\left(100 \mathrm{nmol} \mathrm{l}^{-1}\right)$ for $20 \mathrm{~min}$ to evaluate whether angiotensin II acts synergistically with progesterone. Although each agonist resulted in a significant induction of the acrosome reaction $(P<0.05)$, there was no significant additive effect when both agonists were added in combination (Fig. 3).

\section{Effects of angiotensin II on calcium release}

Angiotensin II (10 or $100 \mathrm{nmol} \mathrm{l}^{-1}$ ) stimulated a rapid but transient increase in intracellular calcium in capacitated spermatozoa from three stallions (Fig. 4). Optimal response (in terms of peak calcium response) in two stallions was $10 \mathrm{nmol}$ angiotensin II $\mathrm{l}^{-1}$ and in one stallion was $100 \mathrm{nmol}$ angiotensin II $1^{-1}$. Intracellular calcium increased significantly $(P<0.05)$ over basal values after the addition of angiotensin II $\left(10 \mathrm{nmol} \mathrm{l}^{-1}\right)\left(279 \pm 11\right.$ versus $393 \pm 41 \mathrm{nmol} \mathrm{l}^{-1}$, respectively) to capacitated equine spermatozoa (Fig. 5). At the same time, there was an increase in the acrosome reaction from $10.4 \pm 1.5 \%$ in controls versus $25.8 \pm 8.1 \%$ and $21.8 \pm 5.4 \%$ in spermatozoa treated with 100 and $10 \mathrm{nmol}$ angiotensin $\mathrm{II}^{-1}$, respectively. When spermatozoa were preincubated with $100 \mathrm{nmol}$ losartan $\mathrm{l}^{-1}$ for $10 \mathrm{~min}$ before addition of angiotensin II, the angiotensin II-mediated calcium influx was completely inhibited (Fig. 6). At the same time, losartan significantly inhibited the acrosome reaction in capacitated equine spermatozoa after the addition of angiotensin II (Fig. 2).

\section{Expression of angiotensin II type 1 receptor in ejaculated spermatozoa}

The angiotensin II type 1 receptor antibody identified a protein band of $60 \mathrm{kDa}$ in ejaculated spermatozoa (Fig. 7).

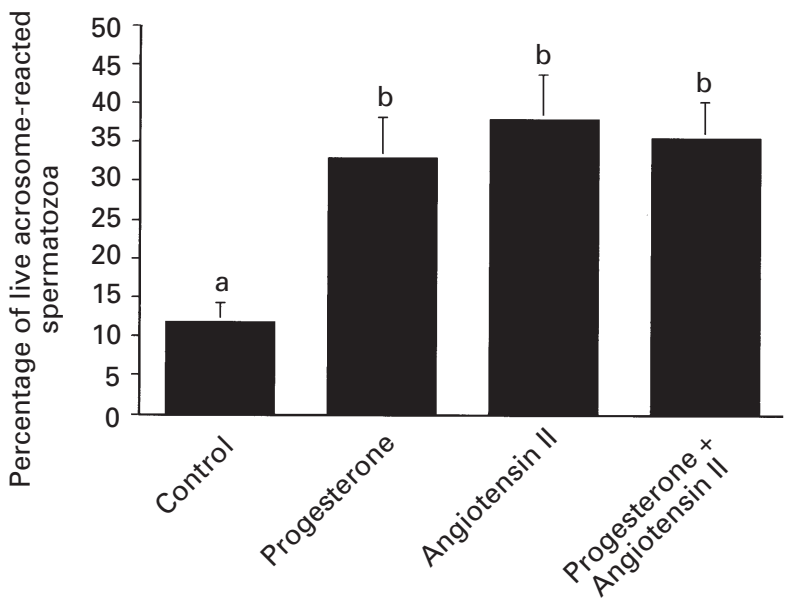

Fig. 3. Synergistic effect of progesterone and angiotensin II on acrosomal exocytosis in capacitated equine spermatozoa. Capacitated spermatozoa were incubated with progesterone $\left(3.18 \mu \mathrm{mol}^{-1}\right)$ or angiotensin II (100 $\left.\mathrm{nmol} \mathrm{l}^{-1}\right)$ alone or in combination for $20 \mathrm{~min}$. Data are presented as live acrosome-reacted spermatozoa as a percentage of total live spermatozoa. Values are means of two ejaculates each from four individual stallions $\pm \mathrm{SD}$. Values with different letters are significantly different $(P<0.05)$.
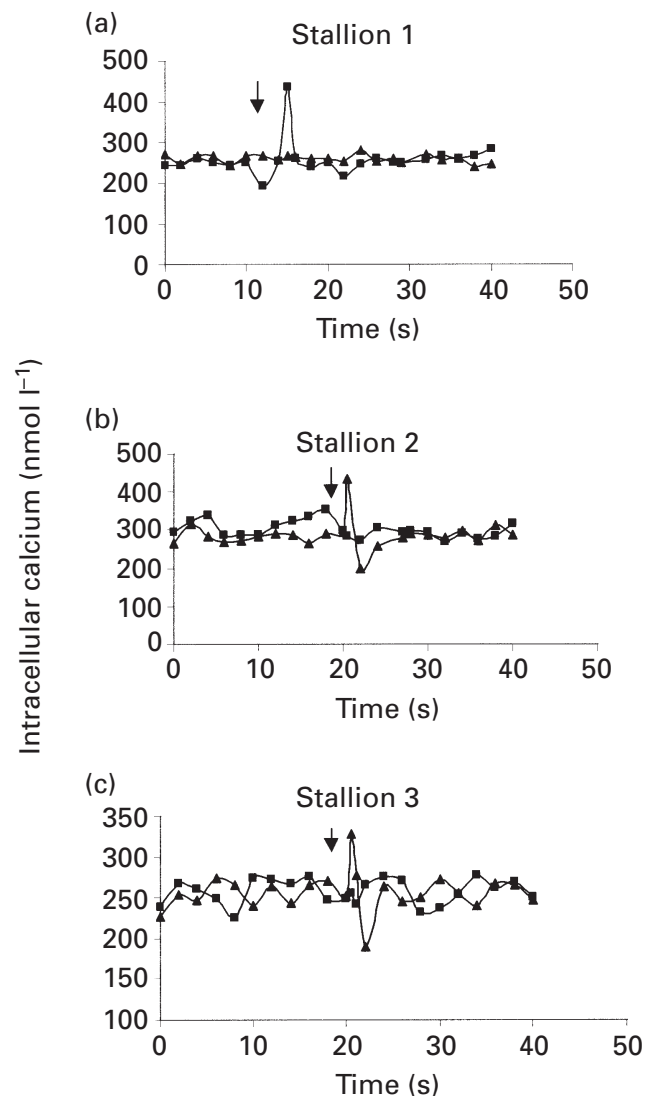

Fig. 4. Effects of angiotensin II on calcium influx in capacitated equine spermatozoa. Capacitated equine spermatozoa were loaded with Fura-2AM $\left(1 \mu \mathrm{mol} \mathrm{l^{-1 }}\right)$ and were incubated with $100(\mathbf{\square})$ or 10 (४) nmol angiotensin II $1^{-1}$. Calcium influx was measured before and after addition of angiotensin II. Results $(a-c)$ are from individual stallions $(n=3)$. Arrow represents the time of addition of angiotensin II. 


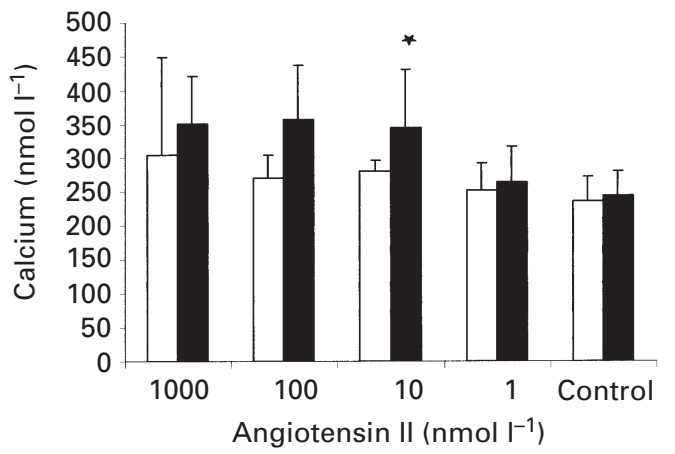

Fig. 5. Mean concentration of intracellular calcium before ( $\square$ ) and after ( $\mathbf{\square})$ addition of different concentrations of angiotensin II. Capacitated equine spermatozoa were loaded with Fura-2AM and were incubated with angiotensin II $\left(1000,100,10\right.$ or $\left.1 \mathrm{nmol} \mathrm{l}^{-1}\right)$. Calcium influx was measured before and after addition of angiotensin II. Values before the addition of angiotensin II are the means of the basal concentrations from all experiments; values after the addition of angiotensin II are the means of the maximum values after angiotensin II addition. Asterisk indicates that there was a significant difference $(P<0.05)$ in calcium concentrations after addition of $10 \mathrm{nmol}$ angiotensin $\mathrm{II}^{-1}$.

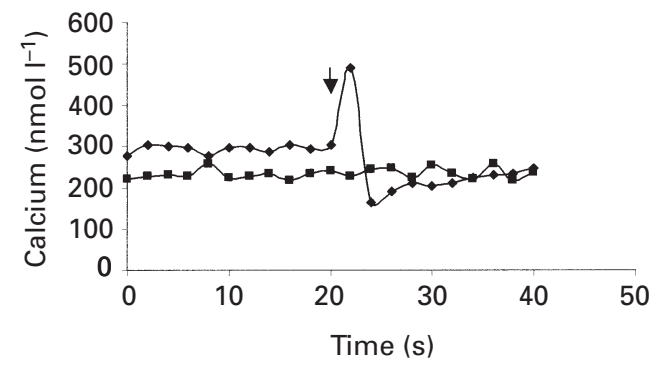

Fig. 6. Effect of losartan $\left(100 \mathrm{nmol} \mathrm{l}^{-1}\right)$ and angiotensin II $\left(100 \mathrm{nmol} \mathrm{l}^{-1}\right)$ on calcium influx. $\bullet$, angiotensin II; $\mathbf{\square}$, losartan + angiotensin II. Capacitated equine spermatozoa were loaded with Fura-2AM and were preincubated with losartan before the addition of angiotensin II $\left(100 \mathrm{nmol} \mathrm{l}^{-1}\right)$. Calcium influx was measured before and after addition of angiotensin II. The graph is from one experiment representative of three similar separate experiments.

Immunostaining of the receptor was seen in the midpiece and tail in non-capacitated spermatozoa (Fig. 8). In contrast, in capacitated spermatozoa, the AT1 receptor was localized over the anterior region of the sperm head, the equatorial segment and occasionally the postacrosomal region in addition to the tail (Fig. 9). The change of distribution of angiotensin II type 1 receptor in capacitated cells appeared uniform and was observed in addition to its expression on the tail.

\section{Discussion}

This is the first study to demonstrate the involvement of angiotensin II in acrosomal exocytosis of equine spermatozoa. This study also confirms previous work in bovine (Gur et al., 1998) and human spermatozoa (Kohn et al., 1998) which indicates that angiotensin II can stimulate acrosomal

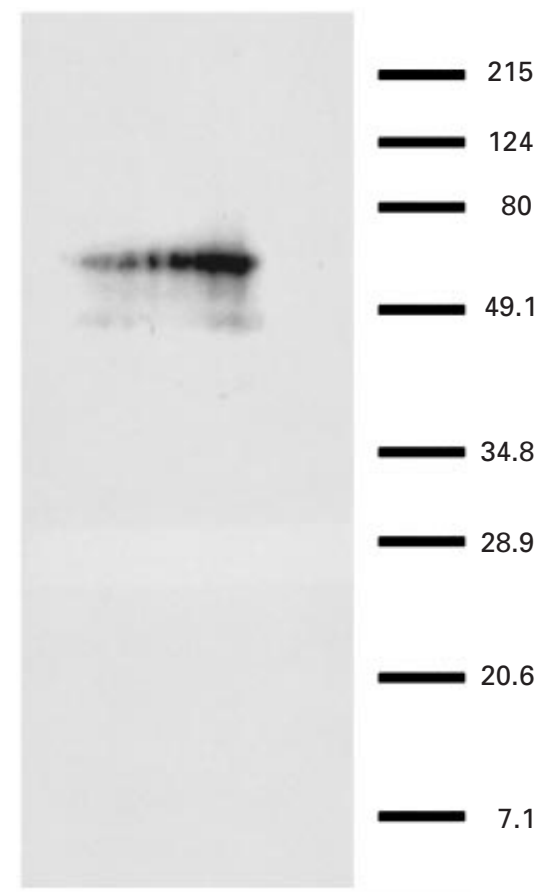

Fig. 7. Protein immunoblot showing angiotensin II type 1 receptor in equine spermatozoa using angiotensin II type 1 receptor specific antibody (AT1R, 1:2000). Molecular masses of prestained broad range markers are indicated.

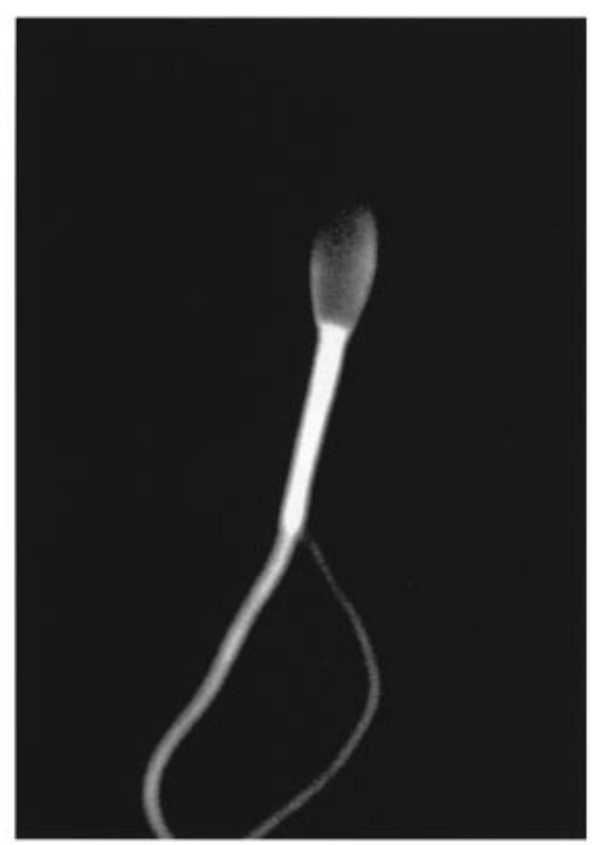

Fig. 8. Immunocytochemical localization of the angiotensin II type 1 receptor in non-capacitated equine spermatozoa. Spermatozoa were fixed and incubated with the angiotensin II type 1 receptor antibody (1:50), followed by a fluorescein isothiocyanate goat anti-rabbit IgG. Staining was observed in the tail and midpiece. 


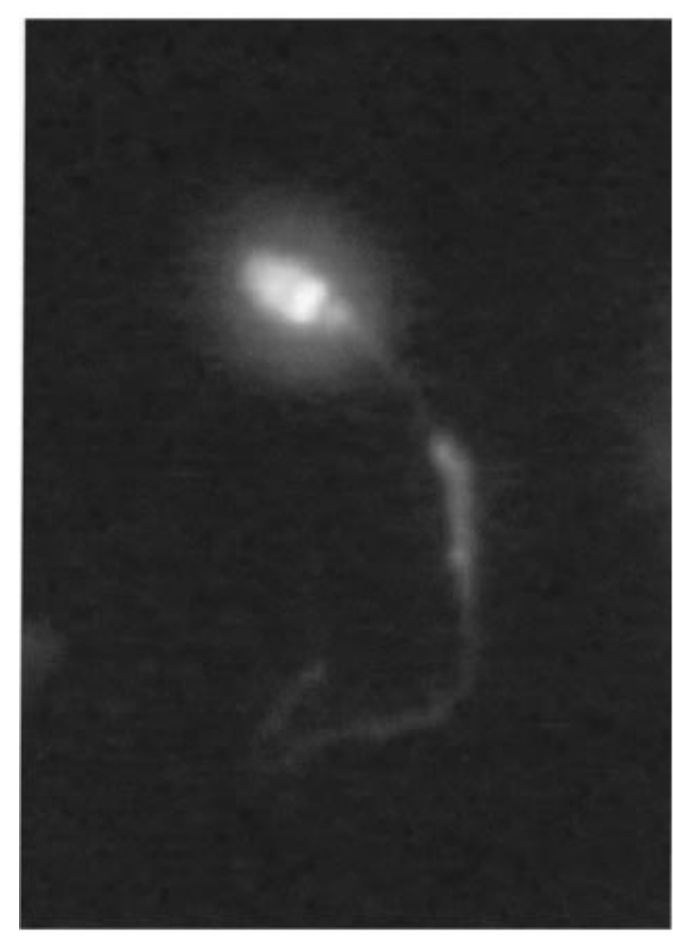

Fig. 9. Immunocytochemical localization of the angiotensin II type 1 receptor in capacitated equine spermatozoa. Spermatozoa were fixed and incubated with the angiotensin II type 1 antibody (1:50), followed by a fluorescein isothiocyanate goat anti-rabbit IgG. Staining was observed over the anterior acrosomal region of the spermatozoa.

exocytosis in capacitated spermatozoa. The acrosome reaction is a critical step for transforming the spermatozoon into a fusogenic cell (Yanagimachi, 1994) that allows the release of hydrolytic enzymes required for the spermatozoon to penetrate the egg. In vivo, the acrosome reaction is regulated by agonists such as the zona pellucida, a glycoprotein coat of the egg, and progesterone, secreted by the cumulus oophorus (review by Meizel et al., 1990). From the present study, it appears that angiotensin II, possibly derived from the female reproductive tract, may also affect acrosomal exocytosis of equine spermatozoa.

Specificity of the response to angiotensin II was confirmed with losartan, a specific angiotensin II receptor antagonist that inhibited induction of acrosomal exocytosis in response to angiotensin II. Losartan (a biphenylimidazole) selectively blocks the binding of angiotensin II to the angiotensin II type 1 receptor. The affinity of losartan is approximately 1000-fold greater for the type 1 receptor than for the type 2 receptor (Griendling et al., 1996). The mediation of angiotensin II induction of acrosomal exocytosis in equine spermatozoa via a type 1 receptor is consistent with a previous report in which acrosomal exocytosis induced with angiotensin II was blocked by losartan in bovine spermatozoa (Gur et al., 1998).

In the present study, the presence of the angiotensin II type 1 receptor was confirmed by using an antibody raised against amino acids 15-24 of the amino terminus of angiotensin II type 1 receptor of human origin (N-10). On western immunoblotting, this antibody identified a protein band of $62 \mathrm{kDa}$ in ejaculated equine spermatozoa. In a previous study by Vinson (1995), a monoclonal antibody (6313/G2) against a specific sequence of the extracellular domain (amino acids 8-17) of the angiotensin II type 1 receptor (Barker et al., 1993) was used to identify a single component of rat spermatozoa with a molecular mass identical to that of the rat adrenal angiotensin II type 1 receptor (approximately $60 \mathrm{kDa}$ ). Gur et al. (1998), using the N-10 antibody, identified a single protein band of an approximate molecular mass of $41 \mathrm{kDa}$ in bovine spermatozoa. The differences in apparent molecular mass of the angiotensin II type 1 receptor may be attributed to differences between species in the degree of glycosylation.

In addition to immunoblotting, the presence of the angiotensin II type 1 receptor on equine spermatozoa was also confirmed by indirect immunofluorescence of both noncapacitated and capacitated equine spermatozoa. In noncapacitated spermatozoa, the angiotensin II type 1 receptor was localized primarily on the midpiece and tail. This finding is similar to those reported by Vinson et al. (1995) in rat and human spermatozoa and by Gur et al. (1998) in bovine spermatozoa and is consistent with a putative effect of angiotensin II on motility (Vinson et al., 1996). A significant effect of angiotensin II on some sperm kinematic parameters was also identified although there was no significant effect on overall motility in non-capacitated equine spermatozoa treated with different doses of angiotensin II (Sabeur et al., 1999).

After capacitation, immunolocalization of the angiotensin II type 1 receptor changed to include the anterior region of the sperm head, the equatorial segment, and the postacrosomal region as well as the tail; however, the angiotensin II type 1 receptor was no longer detected on the midpiece in capacitated spermatozoa. In capacitated bovine spermatozoa, Gur et al. (1998) reported a postacrosomal localization of the angiotensin II type 1 receptor, different from its localization in the noncapacitated spermatozoa. In both equine and bovine capacitated spermatozoa, localization of the angiotensin II type 1 receptor over the anterior and postacrosomal regions of the sperm head would be more consistent with the involvement of the angiotensin II type 1 receptor in the acrosome reaction. It is not clear from the information available at present whether the expression of the angiotensin II type 1 receptor in the postacrosomal segment represents a migration of the receptor from the midpiece or perhaps an unmasking of the receptor already present in that location in capacitated spermatozoa.

Calcium influx after addition of angiotensin II was investigated with the calcium indicator Fura-2AM to examine whether the angiotensin II-induced acrosome reaction is calcium dependent. A transient increase in calcium was observed in equine spermatozoa in response to angiotensin II, which was inhibited by the angiotensin II specific inhibitor losartan. An increase in intracellular calcium is an essential step in the cascade of signal transduction events that leads to the acrosome reaction (Florman et al., 1989; Bailey and Storey, 1994). Zona pellucida agonists and progesterone induce the acrosome reaction and there is a transient increase in calcium (Meizel and Turner, 1991; Sabeur et al., 1996) within seconds after addition of the agonist. In the present study, the angiotensin II-mediated effect on the acrosome reaction also involved a rapid and transient calcium influx. There is 
extensive evidence that a transient increase in intracellular calcium may be part of the intracellular message mediating the effects of angiotensin II in various types of cell (Wang et al., 1989; Maturana et al., 1999). In somatic cells such as rat granulosa cells, Wang et al. (1989) showed a transient increase in intracellular calcium in response to angiotensin II. Other studies have shown the requirement of extracellular calcium in the angiotensin II-induced acrosome reaction. In bovine spermatozoa, angiotensin II was ineffective in calcium-free medium (Gur et al., 1998). Together, these studies indicate that angiotensin II mediates its effect on acrosomal exocytosis via an increase in intracellular calcium, possibly via a $G$ protein linkage. The angiotensin II type 1 receptor has been cloned from mice, rats, cows and humans, and its cDNA encodes a 359 residue protein that contains seven transmembrane regions typical of $G$ protein-coupled receptors (Murphy et al., 1991; Sandberg, 1994).

In spite of evidence gained in vitro in relation to the role of angiotensin II in the induction of acrosomal exocytosis, the physiological relevance of an angiotensin II-responsive acrosomal exocytosis in spermatozoa has not been determined in vivo. A number of studies have reported the presence of RAS in the female reproductive tract. A functional local RAS is present in the ovary, and it is likely that angiotensin II is present in the follicular fluid. The concentrations of angiotensin II in human follicular fluid are higher than those in plasma (Culler et al., 1986; Heimler et al., 1995). As for progesterone, the angiotensin II in the follicular fluid may modulate sperm function. Angiotensin II contributes to the process of ovulation (Pellicer et al., 1988; Andrade-Gordon et al., 1991; Yoshimura et al., 1993), and an increase in active renin and prorenin was found after the LH peak in bovine follicular fluid (Hagemann et al., 1994). Angiotensin II is also involved in oocyte maturation (Yoshimura et al., 1992), ovarian steroidogenesis (Kitzman and Hutz, 1992) and follicular atresia (Feral et al., 1995) via either paracrine or autocrine effects. Angiotensin II was shown to have a stimulatory effect on the frequency of beating of tubal cilia, indicating a potential role in ovum transport. Angiotensin II type 1 receptors are present in the human Fallopian tube, particularly in the ampulla (Saridogan et al., 1996).

All of these studies indicate that RAS is important in the female reproductive tract. On the basis of studies that demonstrate the ability of angiotensin II to stimulate acrosomal exocytosis, it appears likely that RAS in the female reproductive tract may also have a direct effect on sperm function. The action of angiotensin II on the female tract and its role on the acrosome reaction emphasize the multiple roles that this hormone may have in reproductive function. Future studies should address the effect of RAS on spermatozoa within the female reproductive tract.

If angiotensin II acts locally within the female reproductive tract to stimulate acrosomal exocytosis, this hormone might act synergistically with other known agonists of the acrosome reaction. Such synergy has been demonstrated in pig spermatozoa in which two physiological agonists, progesterone and the zona pellucida, have an additive effect on the acrosome reaction (Melendrez et al., 1994). Meizel (1985) hypothesized that the zona pellucida and cumulus-associated molecules act as a back-up system for each other, or synergistically, to ensure the occurrence of the acrosome reaction of the fertilizing spermatozoon. The potential synergy between progesterone and angiotensin II was tested in the present study. Although both agonists stimulated acrosomal exocytosis individually, there was no apparent synergistic effect when the two agonists were used in combination.

Progesterone induces the acrosome reaction in equine spermatozoa (Meyers et al., 1995). Progesterone is secreted in the equine preovulatory follicle before ovulation and luteinization (Lindford et al., 1992) and is likely to be present in oviductal fluids. In the present study, spermatozoa were incubated in a TALP-TEST capacitation buffer similar to that described by Meyers et al. (1995), but for a shorter duration and in the presence of cAMP during the $3.5 \mathrm{~h}$ of capacitation time. Parrish et al. (1998) showed that cAMP supports capacitation in equine spermatozoa, and there is evidence that cAMP has an important role in capacitation (Visconti et al., 1995). Although the idea that cAMP is involved in regulating mammalian sperm function has been proposed for many years, it is only recently that a role for cAMP in capacitation has been established in a few species such as cattle (Galantino-Homer et al., 1997), mice (Visconti et al., 1995) and horses (Parrish et al., 1998). The addition of cAMP to equine sperm suspensions allowed a shorter incubation time and maintained an optimal acrosome reaction in viable spermatozoa. Longer incubation periods were characterized by an increase in non-viable spermatozoa without significant change in the viable acrosome reacting spermatozoa.

In conclusion, this study demonstrates the ability of angiotensin II to stimulate acrosomal exocytosis in capacitated equine spermatozoa. The induction of the acrosome reaction was accompanied by an increase in intracellular calcium. Angiotensin type 1 receptors are present on equine spermatozoa, and there appears to be a change in distribution of the receptor from the midpiece to the periacrosomal and equatorial region of the sperm head during capacitation. Although many studies have been conducted on the effects and the mechanisms of action of angiotensin II in somatic cells, the signal transduction pathways involved in the effects of angiotensin II on spermatozoa and the acrosome reaction remain unclear. Further work is required to evaluate some of the other signalling molecules that are stimulated after binding of angiotensin II to its receptor.

This research was supported by the John P. Hughes Endowment and by the Center for Equine Health with funds provided by the Oak Tree Racing Association, the State of California pari-mutuel fund, and contributions by private donors. The authors thank Jan Roser and the Department of Animal Science at UC Davis for the use of some of the stallions used in this study. They also thank Merck \& Co. and E. I. du Pont \& Co. for providing losartan.

\section{References}

Andrade-Gordon P, Zreik T, Apa R and Naftolin F (1991) Role of angiotensin II in the processes leading to ovulation Biochemical Pharmacology 42 715-719

Bailey JL and Storey BT (1994) Calcium influx into mouse spermatozoa activated by solubilized zona pellucida, monitored with the calcium 
fluorescent indicator, fluo-3. Inhibition of the influx by three inhibitors of the zona pellucida induced acrosome reaction: tyrophostin A58, pertussis toxin, and 3'-quinuclidinyl benzailate Molecular Reproduction and Development 39 297-308

Barker S, Marchant W, Ho MM, Puddefoot JR, Hinson JP, Clark AJL and Vinson GP (1993) A monoclonal antibody to a conserved sequence in the extracellular domain recognizes the angiotensin II $\mathrm{AT}_{1}$ receptor in mammalian target tissues Journal of Molecular Endocrinology 11 241-245

Cross NL, Morales P, Overstreet JW and Hanson FW (1986) Two simple methods for detecting acrosome reacted sperm Gamete Research 15 213-226

Culler MD, Tarlatzis BC, Lightman A, Fernandez LA, DeCherney AH, Negro-Vilar A and Naftolin F (1986) Angiotensin II-like immunoreactivity in human ovarian follicular fluid Journal of Clinical Endrocrinology and Metabolism 62 613-615

Dobrinski I, Ignotz GG, Fagnan MS, Ashley IY and Ball B (1997) Isolation and characterization of a protein with homology to angiotensin converting enzyme from the periacrosomal plasma membrane of equine spermatozoa Molecular Reproduction and Development 48 251-260

Feral C, Legall S and Leyarie P (1995) Angiotensin II modulates steroidogenesis in granulosa and theca in the rabbit ovary: its possible involvement in atresia European Journal of Endocrinology 133 747-753

Florman HM, Tombes RM, First NL and Babcock DF (1989) An adhesionassociated agonist from the zona pellucida activates $\mathrm{G}$ protein-promoted elevations of internal $\mathrm{Ca}^{2+}$ and $\mathrm{pH}$ that mediate mammalian spermatozoa acrosomal exocytosis Developmental Biology 135 133-146

Furuya S, Endo Y, Oba M, Suzuki S and Nozawa S (1993) Effects of epidermal growth factor on human spermatozoa capacitation Fertility and Sterility $\mathbf{6 0}$ 905-910

Galantino-Homer H, Visconti PE and Kopf GS (1997) Regulation of protein tyrosine phosphorylation during bovine sperm capacitation by a cyclic adenosine 3', 5'-monophosphate-dependent pathway Biology of Reproduction $56707-719$

Griendling KK, Lassegue B and Alexander RW (1996) Angiotensin receptors and their therapeutic implications Annual Review of Pharmacology and Toxicology 36 281-306

Gur Y, Breitbart H, Lax Y, Rubinstein S and Zamir N (1998) Angiotensin II induces acrosomal exocytosis in bovine spermatozoa American Journal of Physiology 275 Endocrinology Metabolism 38 E87-E93

Hagemann A, Nielsen AH, Avery B and Poulsen K (1994) In vitro incubation of bovine ovarian follicles: indications for an active and regulated reninangiotensin system Clinical Experimental Pharmacology and Physiology 21 569-575

Heimler I, Rawlins RG, Binor Z, Aiman J, Raff H and Hutz RJ (1995) Elevated follicular fluid angiotensin II and pregnancy outcome Fertility and Sterility 63 528-534

Joyce CL, Nuzzo NA, Wilson L and Zaneveld LJD (1987) Evidence for the role of cyclooxygenase (prostaglandin synthetase) and prostaglandins in the spermatozoa acrosome reaction and fertilization Journal of Andrology 8 74-82

Kitzman PH and Hutz RJ (1992) In vitro effects of angiotensin II on steroid production by hamster follicles and on ultrastructure of the theca interna Cell and Tissue Research 268 191-195

Kohn FM, Muller C, Drescher D et al. (1998) Effect of angiotensin converting enzyme (ACE) and angiotensins on human spermatozoa functions Andrologia 30 207-215

Lax Y, Rubinstein S and Breibart H (1994) Epidermal growth factor induces acrosomal exocytosis in bovine sperm FEBS Letters 339 234-238

Lindford RL, McCue PM, Montavon S and Lasley BL (1992) Long-term cannulation of the ovarian vein in the mare American Journal of Veterinary Research 53 1589-1593

Maturana AD, Burnay MM, Capponi AM, Vallontton MB and Rossier MF (1999) Angiotensin II type 1 receptor activation modulates L- and T-type calcium channel activity through distinct mechanisms in bovine adrenal glomerulosa cells Journal of Receptor and Signal Transduction Research 19 $509-520$

Meizel S (1985) Molecules that initiate or help stimulate the acrosome reaction by their interaction with the mammalian sperm surface American Journal of Anatomy 174 285-302

Meizel S and Turner KO (1991) Progesterone acts at the plasma membrane of human spermatozoa Molecular and Cellular Endocrinology 11 R1-R5

Meizel S, Pillai MC, Diaz-Perez E and Thomas P (1990) Initiation of the human sperm acrosome reaction by components of human follicular fluid and cumulus secretions including steroids. In Fertilization in Mammals pp 205-222 Eds BD Bavister, J Cummins and ERS Roldan. Serono Symposia, Norwell, MA

Melendrez CS, Meizel S and Berger T (1994) Comparison of the ability of progesterone and heat solubilized porcine zona pellucida to initiate the porcine spermatozoa acrosome reaction in vitro. Molecular Reproduction and Development 39 433-438

Meyers SA, Overstreet JW, Liu IKM and Drobnis EZ (1995) Capacitation in vitro of stallion spermatozoa: comparison of progesterone-induced acrosome reactions in fertile and subfertile males Journal of Andrology $\mathbf{1 6}$ $47-54$

Murphy TJ, Alexander RW, Griendling KK, Runge MS and Bernstein KE (1991) Isolation of a cDNA encoding the vascular type-1 angiotensin II receptor Nature 351 233-236

Naz RK and Kaplan P (1993) Effects of epidermal growth factor on human spermatozoa cell function Journal of Andrology 14 240-247

Osman RA, Andria ML, Jones AD and Meizel S (1989) Steroid induced exocytosis: the human spermatozoa acrosome reaction Biochemical and Biophysical Research Communications 160 828-833

Parrish JJ, Susko-Parrish JL, Squires EL and Graham JK (1998) In vitro capacitation of equine spermatozoa Journal of Animal Science $\mathbf{7 6}$ Supplement $\mathbf{1}$ 929

Pellicer A, Palumbo A, DeCherney AH and Naftolin F (1988) Blockage of ovulation by an angiotensin antagonist Science 240 1660-1661

Sabeur K, Edwards DP and Meizel S (1996) Human spermatozoa plasma membrane progesterone receptor(s) and the acrosome reaction Biology of Reproduction 54 993-1001

Sabeur K, Gravance C and Ball BA (1999) Effects of angiotensin II on motility in equine sperm Biology of Reproduction 60 Supplement 1136

Sandberg K (1994) Structural analysis and regulation of angiotensin II receptors Trends in Endocrinology and Metabolism 5 28-35

Saridogan E, Djahanbakhch O, Puddefoot JR, Demetroulis C, Collingwood K, Mehta JG and Vinson GP (1996) Angiotensin II receptors and angiotensin II stimulation of ciliary activity in human Fallopian tube Journal of Clinical Endocrinology and Metabolism 81 2719-2725

Schaefer M (1998) A new prostaglandin E receptor mediates calcium influx and acrosome reaction in human spermatozoa Proceedings National Academy of Sciences USA 95 3008-3013

Tesarik J (1985) Comparison of acrosome reaction-inducing activities of human cumulus oophorus, follicular fluid and ionophore A23187 in human sperm populations of proven fertilizing ability in vitro. Journal of Reproduction and Fertility 74 383-388

Thomas P and Meizel S (1988) An influx of extracellular calcium is required for initiation of the human spermatozoa acrosome reaction induced by human follicular fluid Gamete Research 20 397-411

Vinson GP, Puddefoot JR, Ho MM, Barker S, Mehta J, Saridogan E and Djahanbakhch O (1995) Type 1 angiotensin II receptors in rat and human spermatozoa Journal of Endocrinology 144 369-378

Vinson GP, Mehta J, Evans S, Matthews S, Puddefoot JR, Saridogan E, Holt WV and Djahanbakhch O (1996) Angiotensin II stimulates spermatozoa motility Regulatory Peptides 67 131-135

Visconti PE, Moore GD, Bailey JL, Leclerc P, Connors SA, Pan D, OldsClarke P and Kopf GS (1995) Capacitation of mouse spermatozoa. Protein tyrosine phosphorylation and capacitation are regulated by a cAMPdependent pathway Development 121 1139-1150

Wang J, Baimbridge KJ and Leung PCK (1989) Perturbations of intracellular calcium ion concentrations in single rat granulosa cells by angiotensin II Endocrinology 124 1094-1096

Wong PY and Uchendu CN (1991) Studies on the renin-angiotensin system in primary monolayer cell cultures of the rat epididymis Journal of Endocrinology 131 287-293

Yanagimachi R (1994) Mammalian fertilization. In Physiology and Reproduction pp 189-317 Eds E Knobil and JD Neil. Raven Press, New York

Yoshimura Y, Karube M, Koyama N, Shiokawa S, Nanno T and Nakamura Y (1992) Angiotensin II directly induces follicle rupture and oocyte maturation in the rabbit FEBS Letters 307 305-308

Yoshimura Y, Karube M, Oda T, Koyama N, Shiokawa S, Akiba M, Yoshinaga A and Nakamura Y (1993) Locally produced angiotensin II induces ovulation by stimulating prostaglandin production in in vitro perfused rabbit ovaries Endocrinology 133 1609-1616

Zamir N, Riven-Kreitman R, Manor M, Makler A, Blumberg S, Ralt D and Eisenback M (1993) Atrial natriuretic peptide attracts human spermatozoa in vitro. Biochemical and Biophysical Research Communications 197 116-122 